Western Washington University Western CEDAR

2017

\title{
Que Luchen por sus Intereses (To Fight for Your Interests): Unearthing Critical Counter-Narratives of Spanish-Speaking Immigrant Parents
}

\author{
Kevin Roxas \\ Western Washington University, kevin.roxas@wwu.edu \\ Maria L. Gabriel
}

Follow this and additional works at: https://cedar.wwu.edu/woodring_dei

Part of the Education Commons

\section{Recommended Citation \\ Kevin Roxas \& Maria L. Gabriel (2017) Que Luchen por sus Intereses (To Fight for Your Interests): Unearthing Critical Counter-Narratives of Spanish-Speaking Immigrant Parents, Journal of Latinos and Education, 16:3, 243-262, DOI: 10.1080/15348431.2016.1229618}

This Article is brought to you for free and open access by the Woodring College of Education at Western CEDAR. It has been accepted for inclusion in Woodring Scholarship on Diversity, Equity, Inclusion by an authorized administrator of Western CEDAR. For more information, please contact westerncedar@wwu.edu. 


\title{
Que Luchen por sus Intereses (To Fight for Your Interests): Unearthing Critical Counter-Narratives of Spanish-Speaking Immigrant Parents
}

\author{
Kevin Roxas and Maria L. Gabriel ${ }^{\mathrm{b}}$
}

\begin{abstract}
This article reports on findings from a year-long research project conducted during the 2012-2013 school year in a PK-12 school district, located in the Mountain West region of the United States, utilizing the Photovoice method. The findings in the project point to the important critical counternarratives Spanish-speaking immigrant parents present to the larger school community when given the opportunity to have their voices and perspectives heard and recorded in written form. The article provides teachers, counselors, administrators, and support staff in schools and school districts with insight into the hopes and aspirations of Spanish-speaking immigrant parents and highlights educational practices that address issues of equity and access, as seen through the eyes of the participants in the study.
\end{abstract}

\section{KEYWORDS}

Critical counter-narratives; immigrant parents; immigrant students; social contexts of education

\section{Introduction}

Within the fields of critical multicultural education and teacher education, many researchers have focused on the cultural discontinuity of White teachers in diverse classrooms in urban areas (Gabriel, 2015; Howard, 2006; Landsman \& Lewis, 2006). Although the demographics of students are shifting in public school classrooms in the United States to be more linguistically and culturally diverse, their teachers remain largely White (Bireda \& Chait, 2011; National Collaborative on Diversity in the Teaching Force, 2004). This 'disjuncture in types of backgrounds creates a cultural gap between teachers and their students. Due to this cultural gap, teachers working in schools in the United States do not often match the linguistic, cultural, or experiential backgrounds of the students they serve.

Majoritarian narratives tend to silence or dismiss people who offer evidence contradicting these racially unbalanced portrayals (Yosso, 2006, p. 9). Culturally and linguistically diverse families' voices are often missing from the majoritarian narrative, which "distorts and silences the experiences of people of color" (Solórzano \& Yosso, 2009, p. 136). Counter-narratives interrupt majoritarian narratives by opening up spaces in which people who have been marginalized can share and make public their own stories about their lives and experience, thus moving from the margins to the centers of the dominant discourse within the field of education and in schools more specifically (Castro-Salazar \& Bagley, 2010; McCarty, Romero, \& Zepeda, 2006; Milner, 2008). The increasing enrollment of immigrant students throughout the Mountain Valley School District (MVSD) ${ }^{1}$ provides an illustrative example of the important and pressing need by teachers, counselors, administrators, and support staff to gain a better understanding of the backgrounds, experiences, and cultures of immigrant students and families and to prepare themselves to be more culturally 
responsive and critically conscious of the counter-narratives of the immigrant students and parents they serve in schools. The critical counter-narratives unearthed and shared from Spanish-speaking immigrant parents in this article offer an interruption to the master narratives and an opportunity for a critical consciousness to be developed.

Over the past decade, the MVSD, a preschool-twelfth grade (PK-12) school district in a metropolitan area of northern Colorado, has seen consistent growth in the enrollment of immigrant and English language learner students. At the time of this research study, schools in the district served approximately 358 immigrant students who spoke 71 different languages. However, teachers and administrators throughout the district reported that little anecdotal data existed that expanded on the academic and cultural backgrounds of immigrant students and the families themselves, particularly regarding their resettlement into MVSD and their academic, social, and linguistic needs. This research project aimed to gather data to understand the backgrounds of immigrant students and their families within the district and to address a gap in what we know about immigrant students and their families within the field of critical multicultural education. Subsequently, this article seeks to center the words and stories shared by Spanish-speaking immigrant parents about their experiences in public schools in the United States as part of a larger Photovoice project completed within the district which included elementary, middle school, and high school participants. All created Photovoice posters were shared with district personnel and community at the conclusion of the project in several exhibit formats.

This article reports on findings from a year-long research project which used the Photovoice method (Gagne, Bowers, Russinova, Bloch, \& McNamara, 2010; Guerrero \& Tinkler, 2010) during the 2012-2013 academic school year in the MVSD. The findings in the project point to the important critical counter-narratives Spanish-speaking immigrant parents present to the larger school community when given the opportunity to have their voices and perspectives heard. The overall project and article provide schools and school districts with important information and insight into the hopes and aspirations of immigrant students and their parents and highlight educational practices that address issues of equity and access for immigrant families.

\section{Immigrant parents and parental involvement in schools}

Latino immigrant parents often report feeling marginalized in schools due to race, class, and cultural differences between themselves and the teachers of their children. Parents share that teachers often do not treat them as partners in the education of their children and can view parents from a deficitoriented perspective of not caring about the educational achievement and success of their own children (Guerra \& Nelson, 2013; Ramirez, 2003; Valencia \& Black, 2002).

Despite the existence of Latino parents' negative orientation by teachers within schools, educational research indicates a very different story. Although Latino parents may not always be visibly participating at school according to taken-for-granted school norms employed by their teachers, they are still participating at home with the education of their children by helping with homework, finding educational resources within the community for their children, speaking with their children about the importance of education or, if they do not actually know the homework, just being present with their child during homework time at home (Auerbach, 2007; Jasis \& Ordonez-Jasis, 2004, 2012; Lopez, Scribner, \& Mahitivanichcha, 2001). Indeed, research studies reveal that Latino parents want to be more involved in the education of their children and want to share their hopes to be partners with teachers and other educators in the school.

As such, Latinos place great emphasis on the academic success of their children and see the importance of education in their child's future (Guerra \& Nelson, 2013; LeFevre \& Shaw, 2012; Solorzano \& Yosso, 2001) and hence, it is imperative for educators (1) to work to redefine parental involvement with a more inclusive perspective (Guerra \& Nelson, 2013); (2) to change the often deficit-based master narrative to draw on family's strengths (Gaetano, 2007); and (3) to begin to listen to the critical counter-narratives Latino parents bring to the schools that their children attend 
to shift the impact of master narratives of Latino parental involvement (Delgado-Gaitan, 1994; Solorzano \& Yosso, 2002).

\section{Critical counter-narratives}

Based upon the work of critical race theorists, researchers and other community-based educators work collaboratively with people who have been marginalized in schools and other community settings to uncover their own critical counter-narratives. Within research projects and communitybased action research, spaces are created within the project or within data collection that are grounded in the experiences and the indigenous knowledge of people of color and designed to uncover strengths-based counter-narratives that speak against deficit paradigms. These stories then work to challenge taken-for-granted stereotypes that exist in society and provide a foundation upon which educators can begin to re-think school practices and institutions that do not always provide equal access and opportunity for academic success for immigrant children and parents who have been marginalized in schools and society (Stanley, 2007; Yosso, 2005).

In the case of Latino immigrant parental involvement, these counter-narratives serve to challenge dominant perspectives of deficit-based parental approaches and perceived lack of interest in education and instead advance alternative strengths-based perspectives on parental involvement in schools. One way to examine this alternative perspective would be through the concept of educación in which Mexican or Spanish-speaking immigrant families refer to the education that happens at home in the development of good morals, respect for others, and the persistent encouragement to be a person respectable in the eyes of other members of society (Auerbach, 2007; Valenzuela, 1999; Vélez-Ibañez \& Greenberg, 1992; Yosso, 2006).

\section{Unearthing immigrant parental involvement through critical counter-narratives}

As educators begin to re-examine and re-imagine what it means for immigrant parents to be involved in public schools, the use of critical counter-narratives is one way to build a foundation upon which to move this work forward. If we seek to re-think the ways in which immigrant parents can be involved, we need to consider the ways they are already involved in the education of their children and the different ways this parental involvement manifests itself from different cultural perspectives. For example, although some parents may not be able to consistently come to the parent-teacher meetings held right after school, scheduled to suit the teacher's convenience but which may not fit the parents' work schedule, this does not mean these same parents are not staying up late with their children to help them with their homework, even though they may not know all of the academic content themselves or are learning English in a parallel process with their own children. Indeed, in this article, we suggest that parents from immigrant backgrounds bring their own wealth of experience, funds of knowledge, and dedication to schools and classrooms that are often not acknowledged by teachers and formal institutions such as public schools (Gabriel, 2011; Ceballo, 2004; LeFevre \& Shaw, 2012; Moll, 1992; Vélez-Ibañez \& Greenberg, 1992).

Through the use of the Photovoice (Gagne et al., 2010; Guerrero \& Tinkler, 2010), we hope to provide additional ways to uncover and unearth the different knowledges and strengths Latino immigrant parents bring to public schools and the critical and insightful counter-narratives they present to educators in public schools today (Auerbach, 2007; Villenas \& Deyhle, 1999).

\section{Methodology}

\section{Photography and narrative as educational interventions}

Photovoice is a participatory action-based research process that allows its participants to tell their own stories through photo exhibitions, public presentations, and school displays. Originally used 
within the field of public health to provide opportunities for marginalized populations to express themselves (Wang, 1999), Photovoice has also been used to help empower members of the homeless community, youth in after-school organizations, and pregnant and parenting teens (Strack, Magill, \& McDonagh, 2004; Wang, Cash, \& Powers, 2000) and allows participants to represent their point of view and everyday lived realities. Participants are asked to discuss the visual images they have chosen or photographed and to then create public presentations with text that they write which explains the images. Photovoice allows members of marginalized communities to share their experiences with others and empowers them to become positive change agents within their communities. While qualitative methodology is questioned by quantitative methodologists and the academy is often at odds about its effectiveness, Photovoice maintains high standards and allows for self-empowerment of the participants, which further creates a socially just standard for educational research.

\section{Background and context of the study}

Mountain Valley, the pseudonymous site of the research study, is located about an hour from Denver, Colorado, and is among of the most populous school districts in Colorado. In the last decade, Mountain Valley has experienced rapid population growth because of its close proximity to the urban sprawl of the Denver metropolitan area, the rapid growth of technology firms located in the city itself, and the continued growth of a large state university located adjacent to the city's downtown district.

The Mountain Valley School District (MVSD) has also seen consistent growth over the last decade in terms of demographic shifts and the enrollment of immigrant and English language learner students. According to a recent district report, every school in the district has immigrant students enrolled with an overall student population of at least 358 immigrant students speaking 71 languages. Currently, students are self-identified within the district as $74 \%$ White, $18 \%$ Hispanic/ Latino, 3\% Asian, 1.5\% Black/African American, and 3\% Other. Twenty-eight percent of the student population in the district participates in the Free/Reduced Lunch Program while $7.5 \%$ of the students participate in the English Language Learners Program.

\section{Data collection and analysis}

The year-long project described in this article was created to provide teachers, counselors, administrators, and support staff in MVSD schools with information about immigrant students and their families enrolled within the district. This information was gathered through photographs, narratives, interviews, and community engagement with immigrant students and their families through a collaborative Photovoice project. The data collection process sought to both empower and engage immigrant students and families in the MVSD through culturally responsive methods that ask students and families to share their own stories and backgrounds of their move to the MVSD. Individual incidents within the data were compared and contrasted with other incidents and related themes were grouped to aid in the understanding of processes involved in the experience of participants across multiple photos, written narratives, and individual interviews (Leech \& Onwuegbuzie, 2008). Three levels of coding were used in the data analysis process, including open coding, axial coding, and selective coding. These codes were used to write frequent memos that identified evidence-based themes represented by participants within this research project (Charmaz, 2006; Corbin \& Strauss, 2008).

\section{Procedure}

This article provides findings from working with Spanish-speaking parents who had children enrolled in schools throughout the district. Spanish-speaking parents of identified immigrant students were invited to attend an informational meeting hosted by the university research team 
at the school where the further classes took place. The meeting was an invitation and introduction to a five-week class utilizing Photovoice. Two bilingual and bicultural school-to-family liaisons with long-term relationships with the identified families recruited the participants and attended the informational session and the follow-up class sessions to serve as interpreters and assist in translation of text on the final posters. The research team consisted of two educational researchers (one White male and one Filipino male) and a graduate assistant (White female), who created and conducted workshop sessions with the interested Spanish-speaking immigrant parents to better understand the experiences of immigrant families within the MVSD and the aspirational hopes of parents and other caregivers for their children. Parents were asked to express themselves through photographs they took of themselves and their home communities. Parent participants were also asked about the challenges and opportunities they faced as parents in the school district.

Six parents attended five two-hour sessions in which they analyzed visual images, discussed and practiced using principles of photography and design, took their own photographs of important images and moments within their lives, and began to write personal text to accompany their photographs. During these weekly meetings, project facilitators sought to create a welcoming environment that allowed Spanish-speaking immigrant parents the opportunity to share about their experiences openly, talk with one another about their experiences in school, and create a common vision of what they hoped schools could provide for their children and what they hoped they, in turn, as parents, could provide for schools. The research team hoped to create a welcoming environment for these workshop sessions by hosting the classes in a familiar setting (e.g., the school many of the parents' children attended), offering a meal at the beginning of each class, holding free on-site child care, and having bilingual and bicultural school-to-family liaisons attend each of the sessions to help with translation and overall support. Members of the research team also shared their own photographs and personal stories throughout the workshop sessions to further build relationships and trust.

In between classes, parent participants were asked to take photographs at home and at their children's school to document their lives in and out of school, and their hopes for their children's educational futures. Parents took these photographs during the week and then brought them to weekly meetings where the photographs were digitally displayed, and parent participants took turns discussing the visual imagery and personal meaning behind each shared image. Once parent participants felt comfortable taking photographs and writing about their personal experiences and stories, workshop facilitators then asked parents to create and design their own Photovoice posters. Parent participants were given a template with a blank design template with spaces for photographs and text.

All parents spoke English as a second language. To allow parents to write in a language that they were most comfortable with, facilitators gave parents the choice of what language to use for the poster. All parents chose to write in their first language of Spanish. Parents wrote all text in Spanish and indicated which photographs they wanted included in their posters. Once the drafts of the posters were completed, project facilitators and staff within the district then translated all of the Spanish text into English. Text in the final posters for parent participants was written in both Spanish and English. ${ }^{2}$

One major concern for project facilitators was the translations from Spanish to English. Project facilitators double-checked translations by sharing posters in both Spanish and English with project participants to correct any incorrect translations. Facilitators then revised the posters one additional time to make sure to capture the spirit and intent that participants shared with them during the member-check. After all revisions were made, facilitators interviewed the participants about their posters. Parents then had one more opportunity to express their ideas in even greater detail with their facilitators and to elaborate on themes introduced in their photos. 
The project culminated with a month-long exhibition of the work created and presented by project participants, including poster presentations by immigrant parents for their own children and other members of their family, for friends of participants, members of the Mountain Valley community, teachers in the district, and other school staff. The exhibition was held at a gallery space in the downtown area of the school district. A special reception was held halfway through the exhibition with about 250 audience members in attendance in order to celebrate, share, and have a community discussion about the work of all Photovoice project participants.

These exhibitions gave these immigrant parents and members of their families multiple opportunities to share their personal stories with school stakeholders via presentations they created, and catalyzed a space where immigrant family members and school staff could dialogue and learn from one another. Parents expressed pride in their individual Photovoice posters as well as the collective work completed by their fellow parents from the Spanish-speaking community within the school district.

\section{Findings from the research with immigrant parents}

Four major themes from the research project with Latino immigrant parents emerged through a thematic analysis. Participant narratives embedded within the Photovoice project posters and shared during individual interviews were analyzed using constant comparison analysis (Corbin \& Strauss, 2008). What follows is a general overview and explanation of each major theme and then specific examples of how the theme was present in parent interviews, observations of work sessions with parents, and posters created by the parents themselves. The themes will provide critical counternarratives that detail how immigrant parents thought about and discussed the importance of education within the lives of their children and their own contributions to the success of their children in public schools with the MVSD.

Theme 1: Parent's own immigrant experience impacts the importance of their child's education One of the major themes that emerged from the data with Latino immigrant parents was the omnipresent idea that the opportunity for education and schooling was the most important reason why parents had immigrated to the United States in the first place. Despite the obstacles parents might face in their journey of immigration, the possible roadblocks of learning English as a second language and learning a new educational system, and negative stereotypes they might face or have already faced, parents were steadfast in their belief that the public school system provided their children with important opportunities that were not always available in their country of origin. Hence, these parents stressed throughout the workshops, interviews, and in their writing for their final posters the critical role of perseverance over any obstacles they might face and the utmost importance of success in school as a prerequisite for success in one's life and in one's future.

Ariela, one of the parent participants, spoke about how, unbeknownst to her, she was originally born in Mountain Valley and how her family eventually moved back to Guadalajara, Mexico, to live when she was a one-year-old baby. Her father was killed when she was nine years old and her mother and younger sisters had to work hard to survive without him. Ariela writes how she, her mother, and four younger sisters struggled to survive by planting corn and beans so they could feed themselves. They milked cows, prepared cheese, and made tortillas so they could continue to live on the ranch. She writes that, when she grew up, they had "no electricity, no gas, no drinking water" and that her "house was made of adobe earth." In terms of education, she shared that she had few opportunities to attend formal school, but that she still knew the importance of education in her own life: 
Ariela: Tampoco habíamos asistido a la escuela. Lo poco que aprendimos fue por nuestra madre que nos enseñó el abecedario; nuestro pizarrón era la pared de la casa, y en lugar de tiza, era un pedazo de carbón, y era muy divertido. También participamos en el programa CONAFE. Eran personas que venían a ayudar a los niños en las primeras enseñanzas.

[We had never attended school either. The little bit we knew, we learned it from our mother who taught us the alphabet. Our blackboard was the wall of the house, and instead of chalk, she used a piece of charcoal, and we had a great time. We also participated in the program called CONAFE. People would come to teach basic learning to small children.]

At the age of fourteen, Ariela learned that she had a birth certificate that listed Mountain Valley as her birthplace and she had a social security card. With this, she realized she could move to the United States and try to obtain a formal education. She and her sister decided to move to Mountain Valley and start a new life. Originally, she had plans to study in school, but when she arrived in Mountain Valley, an uncle put Ariela and her sister to work at a construction site and soon she found herself working two jobs so that she could earn a living and contribute to the household expenses of the extended family with whom she was living. Despite these struggles, Ariela persevered and slowly was able to obtain a string of jobs within the city of Mountain Valley, each for better pay and greater job security. She eventually married and now has three children in the MVSD. She writes that her path towards an informal and formal education has not been easy, but it has helped her better appreciate the importance of education, both for her and her three children.

Ariela: Reconozco que tuve una niñez muy dura, y yo era la mayor de mis 5 hermanas; no tener escuela en español, y tampoco haber aprendido en inglés para poder defenderme. El inglés que he aprendido fue por mi trabajo, mis hijos y necesidad de comunicarme con la gente en este estado. Me gusta colaborar con las escuelas para saber un poco más, comprender a mis hijos, conocer a más personas que te ayudan a ver las cosas de otra manera, como compartir idea y conversaciones, y aprender la cultura de mi país del cual estuve ausente casi por 15 años y el que ahora es de mis hijos.

[I realize I had a very hard childhood; I was the oldest of 5 sisters. I wasn't schooled in Spanish, nor did I learn English to be able to defend myself. The English I have learned has been through my work, my kids, and the need to communicate with people in this State. I like to collaborate with the schools so I can learn more, understand my children better, get to know more people who help me see things in a different way, such as sharing ideas and conversations, and learn my country's culture, from which I was absent for almost 15 years, and it is now my children's country.]

Through her interviews and her final poster, Ariela provides teachers with important context for understanding how an immigrant parent might face obstacles in his/her life prior to and during his/ her move to the United States. Ariela was not given the opportunity to learn how to read and to write as a child because she was asked by her mother to stay home to take care of the younger children in her family. She eventually did learn how to read through a family literacy and empowerment program that visited her village in Guadalajara. The discovery of her social security number and card then started the process of a "new life" for her and provided her with unforeseen opportunities that she now wanted to pass on to her own children. Through her perseverance through these obstacles in her life, Ariela developed her belief that education was a gift and an opportunity for a better life for her and for her children, and she dearly wanted her children to be successful in school and to work hard to achieve their goals. 
Another parent in the study, Elizabeth, spoke frequently during parent meetings about la herencia para mis hijos, or the inheritance (of education) for her children. She often talked about the idea that she and her husband might not "be able to leave them much in terms of money or land, but I can still give them an inheritance in the form of an education." In one of her interviews, Elizabeth spoke repeatedly about how the United States offers opportunities in life that immigrant parents and their children need to try and access, and how much she wanted to support her own children in everything they wish to do because she believed they can achieve anything they want with the support of their parents, teachers, and access to opportunities for education.

Elizabeth: Que luchen por su intereses. Que este es un país de oportunidades hay que aprovecharlas. Y que apoyen a sus hijos en todo lo que quieran hacer, porque ellos lo pueden lograr. Ellos pueden hacer lo que quieren aquí, siempre y cuando tengan un apoyo. Si lo han logrado niños que a lo mejor no tienen el apoyo, y lo han logrado, imagínese si todos apoyamos a nuestros hijos.

[They [The parents] should work hard for what they want. This is a country of opportunities, and we have to take advantage of them. They [parents] should support their children in all they want to achieve, because they can succeed. They can do anything they want to do here, as long as they have support. If children, who may not have had any support, have been able to accomplish things, imagine if we all supported our children!]

Interviewer: ¿Sería distinto? [Would it be different?]

Elizabeth: Sí, sería distinto. [Yes, it would be different.]

In their interviews and during weekly meetings with parents, both Ariela and Elizabeth repeatedly shared their beliefs about the promise and opportunity of public school in the United States. The words they shared with other immigrant parents and project facilitators stand squarely in the face of deficit narratives about Latino immigrant parents which state that they do not value public education in the United States and do not show interest in their children's education. Indeed, every parent who participated in the research study echoed Elizabeth's beliefs that education was the inheritance or gift they hoped to leave for their children.

Theme 2: Parent's use of their funds of knowledge as an asset in public schools to overcome obstacles to parent involvement

Another important theme that emerged from the project was the focused and intentional perseverance of immigrant parents over obstacles they faced as they sought to find employment for themselves and public schools for their children to attend, and the multifaceted ways in which these parents employed personal and cultural funds of knowledge to overcome these obstacles (Moll, Soto-Santiago, \& Schwartz, 2013). Throughout the project, parents continued to share stories of obstacles they faced in finding employment in the city of Mountain View and the stereotypes they often faced in the local communities. These stereotypes included the negative perception of immigrant families as not contributing to the local economy by failing to hold steady employment, their perceived ignorance of the public school system and the English language, and the outright racism they faced when out at stores, at schools and, more generally, in public spaces within the community.

In direct contrast to these external stereotypes, parent participants in the study reported a wide array of strategies they used to become successful in the city of Mountain View, both in the different jobs they had at their workplaces and when working with teachers at their children's schools. Throughout the study, parents reported how they drew upon their own personal and cultural funds of knowledge to help their children in school and how often these contributions were not acknowledged by their children's teachers. In addition to helping their children with information 
they might need for their nightly assignments, parents also stressed that they helped their children by providing them with encouragement and hope through their shared testimonios of leaving their home country, the strength of their families and home culture, and the sacrifices different people made within their families to allow their children to be in the United States. Often, these stories were drawn from their own family experience about the importance of perseverance through difficult circumstances, the importance of working hard and staying focused in schools, and having goals for the future. Parents also supported their children through both visible means (for example, serving as homeroom parents for the school year for their child's classroom) and invisible means (for example, tutoring their children at home on subjects they had strengths in and finding other parents from the immigrant community to help their child with subjects they did not know).

Carolina, an immigrant parent of three children in the MVSD, spoke repeatedly about how she continually relied upon the knowledge and tenacity she possessed to learn to find employment in the US and how these "survival skills" outside of the school, as a worker, helped her at school in her role as a parent. In the following excerpt from one of her interviews, Carolina talks about how she eventually found work at a hospital, even though, at the time, she actually did not know much English at all. The story she shares points to her ingenuity and willingness to work with great effort to learn English.

Carolina: Y yo veía que todos trabajaban, y entonces yo decía, yo también quiero trabajar y quiero ayudar a mi esposo, y quiero salir de la casa porque vivía en un "basement," y eso era como que me tenían como encerrada. Entonces un día llegó una amiga, y yo por esa persona llegue a trabajar en Mountain Valley Hospital; fue mi segunda escuela. Sí había gente que hablaba español, y mi supervisor hablaba español, pero a él no le gustaba que hablara español, y quería que habláramos inglés para que aprendiéramos. Entonces cuando fui a la entrevista y me dijo que me iba dar el trabajo; pues allí yo me propuse aprender inglés. $Y$ pues le tuve que mentir porque le dije que hablaba inglés, pero en realidad hablaba bien poquito, y solo hablaba lo más básico que me habían enseñado en mi colegio en México, que son palabras como "apple," "chair" y no sabía conjugar los verbos. Y yo dije, pues hijole, no me gusta mentir, entonces tengo que aprender porque no me gusta mentir. Entonces yo ponía la televisión y escuchaba el radio y cualquier libro que me interesaba, pues yo intentaba de tratar de entender lo que decía el libro. Entonces esa fue mi gran escuela, y por eso es que hablo un poquito de inglés.

[I saw that everyone was working, and I thought to myself that I also wanted to work, and help my husband. I wanted to get out of my house because we used to live in a basement apartment. It felt like if I were in a prison. One day, a friend of mine came to visit, and thanks to her, I started working for Mountain Valley Hospital. It was like my second school. There were people over there who spoke Spanish, and my supervisor also spoke Spanish, but he did not want us to speak in that language, so we could learn English. When I went for the interview, and he said he was going to give me the job, it was then when I decided to learn English-I had to lie to him during the interview-I said I knew English, but the truth is, I only spoke a little bit of English. I only knew the basics I had learned in my school in Mexico, such as apple and chair. I did not know how to conjugate verbs. I said to myself, "Oh boy! I don't like to lie, so I better learn English." I used to turn on the TV and the radio, and pick up any book that looked interesting and really try to understand what it said. That was my big schooling, and that is the reason why I speak some English.]

Although, on the face of it, this excerpt refers to experiences Carolina had in terms of employment, during the project she repeatedly made parallel connections between these experiences she had in the workplace and how she mapped what she learned from work onto her experiences as a parent in schools. For example, although she did not always know the specialized codes and academic language teachers and other parents were using at the schools of her children, Carolina was never deterred from getting involved at each of her children's schools through volunteering to be the 
homeroom parent or helping out with fundraisers for the activities of her children's classroom. Carolina knew that she could not always attend functions that happened during the course of the school day because of her own work schedule. However, she always tried to sign up for parent duties that happened after school, before school, or that she could do on her own time on the weekend or at night when she was not working. Carolina was known throughout the three schools her children enrolled in as a "master fundraiser" for classroom activities through her willingness to make tamales and organize tamale sales to raise funds for school trips.

One day she attended a back-to-school night with her husband, and the teacher asked for volunteers to help make piñatas to celebrate the upcoming birthdays of children in the classroom. Carolina volunteered right away. As she and her husband drove away that night from the school, he asked her why she volunteered when she knew neither of them knew how to make them. She replied, "It doesn't matter. We will learn how to make piñatas. What matters is for us to give as much as we can and be present as much as we can in the classroom, even if we physically can't be present. In this way, we help all children be motivated and learn in our child's classroom." When asked to elaborate more about this particular story, Carolina pointed out that it was important for her to volunteer in order to make this personal connection with the teacher so she could better understand what was happening in her child's classroom and as a way to build connections between the school, other parents, other students, and her home and family.

Indeed, throughout all of her interviews and written work, Carolina continued to return back to the idea that all parents, but especially immigrant parents, have strengths and gifts that they can bring to school settings and that they have to be willing to share these gifts with the school community so as to make the school environment better and also "more beautiful" for all children and teachers who attend the school. Through the weekly meetings with parents, she shared that her husband's leather handiwork (such as embroidered belts, vests, and wallets) had also been donated for silent auctions for school fundraisers. In her final poster for the project, Carolina writes:

Carolina: Si y la gente no hace las cosas que les gusta hacer como cantar y no lo hacen, y si lo hicieran pudieran hacerte feliz, tal vez no económicamente, pero pudieran agradar a otra gente también. Creo que todos tenemos algo que enseñar; creo que todos tenemos el potencial de compartir algo bonito con otros y principalmente con nuestros hijos.

[If people did the things they love to do, such as singing, that would make them happy. Maybe not economically, but they could also please other people. I think we all have something to teach. I think we all have the potential to share something beautiful with others, especially with our children.]

Carolina here underscores the idea that we all have something to teach and something beautiful to share with others. In her final poster, she provides some images of herself as a photographer, master cook, and her husband as a craftsman who likes to create leather belts, bags, and vests. For all of these hobbies and individual pursuits, she was able to find a way to bring these strengths and specific funds of knowledge she and her husband had into the classrooms and schools her children attended within the MVSD. Her final poster for the project ends with the following statement:

Carolina: A mí me encantan las escuelas, y traté de ser voluntaria en mi tiempo libre para aprender el system de aprendizaje, y así poder ayudar a mis hijos a tener éxito hoy y siempre.

[I love the schools and I tried to volunteer in my free time, so I could learn about the system, and in that way, help my children be successful, today and always.] 
Theme 3: Parents wish to be partners and collaborators with teachers in the education of their children

Another major theme that was present in all parent responses throughout all phases of the project was the genuine desire of parents to be partners with their teachers in the education of their children. Parents wanted strong communication between the school and their respective homes because they saw the significance and importance of being connected. Though they could not sometimes attend all school functions due to the inflexibility of their own work schedules, parent participants were keenly aware of the importance of being involved in the life of the school, whether it be through working on fundraisers for the school, serving as parent classroom representatives, or supporting various after-school sports and clubs at the school.

They understood that at these functions important information about the classroom environment would be shared. They also saw that, through their presence at school, they could signal to their children their knowledge of the school milieu and their attention to what and how their children were doing at school.

Elizabeth, a parent of three immigrant children, believed that schools were places where immigrant parents could volunteer and provide service to the school community. Through this service, the students and teachers in the school could benefit. As important to Elizabeth, however, were the ways in which her own children could notice the contributions their parents could bring to the school community. During one of her interviews, Elizabeth reminded her fellow parents of the importance of parental involvement.

Elizabeth: Pueden acercarse a la escuela. Allá hay muchas oportunidades para hacer voluntarios. $Y$ esto es importante porque los niños se fijan mucho, se sienten orgullosos de nosotros de que no solamente podamos trabajar y hacer comida. También podemos hacer actividades en la escuela, para y por la escuela, y para apoyar la escuela, y por ellos. Yo creo se sienten orgullosos de nosotros cuando nos ven en la escuela.

[You can visit the school. There are many opportunities at the school to volunteer, and this is important because children notice everything, and feel proud of us, not only because we work and prepare food, but we can also do activities for the school, to help and support the school, and for our children as well. And I think they feel proud when they see us at school.]

Here, Elizabeth underscores her belief that children will be proud of seeing their parents become active contributors to the school community in school activities and consequently will be more motivated themselves to be positive contributors and learners within the school itself.

Rosario, another immigrant parent, added that parents want to share with their teachers the life and career goals they and their children have for the future and how teachers in school can help them achieve these goals. Rosario makes the connection between the kinds of occupations immigrant children aspire to in the future and the types of support they consequently need from teachers and other support staff in the school when she states:

Rosario: Nosotros queremos que los maestros sepan que venimos a este país a superarnos y a sacar adelante a nuestros hijos. Ellos también quieren ser alguien importante como un maestro, un ingeniero, un veterinario o un bombero. Quieren ser una persona con educación; es por eso que los niños les gusta mucho la escuela. Ahí pasan muchísimas horas del día, y ahí hay muchas personas que se preocupan por ellos como los maestros, los consejeros, las enfermeras, las personas que están en la cafetería.

Por eso es cierto que dicen que los maestros y los padres debemos trabajar juntos para que los estudiantes puedan triunfar en sus grados y en el futuro, con educación. 
[We would like teachers to know that we came to this country to improve ourselves and to help our children get ahead. Our children also want to be someone important, such as a teacher, an engineer, a veterinarian or a fireman. They want to get an education. That is why they like school so much. They spend so many hours of the day there, and at school there are many people who care for them like their teachers, counselors, nurses, and the people who work at the cafeteria.

It's true that parents and teachers should work together so that all students can succeed in their grade levels, and in the future, with education.]

According to Rosario, when parents and teachers work together collaboratively in the service of all children, then students can succeed, both in school and in their plans for the future once they leave school. Luis, a parent of three children in the MVSD, takes the idea of the importance of parent-teacher collaboration one step further and adds that parents are there to help and be "counted on" when teachers need support in resolving any problems or questions. He states:

Luis: Que sepan que cuentan con nosotros los padres, para resolver cualquier problema o pregunta, y que estamos dispuestos a ayudar en lo que podamos para el desarrollo cultural de nuestros hijos. [I want them [teachers] to know that they can count on us parents, to find a solution to any problem or question, and that we are willing to help in any way we can to further the cultural development of our children.]

Elizabeth provides one of the most poignant examples of the parents' repeated calls for stronger parent and teacher partnership and collaboration with this final excerpt for this section. In one of her interviews with the research team, she spoke about how one of the three children in her family brought home a "B" as a grade. Thinking that Elizabeth would not speak directly to her teacher due to her emerging English language skills, her child was surprised when Elizabeth actually did go and speak to the teacher at the school and learned that her child was not handing in homework on a regular basis.

Elizabeth: Bueno, muchas veces, bueno, si uno de mis hijos y tiene una mala nota. Por ejemplo, una vez llegó mi hijo y traía una $B$, pero él me dijo: "No! pero yo me saque una A," pero solo me dijo esto. Entonces yo me enojé, fui a la escuela y hablé con su maestra; era geografía. Entonces yo le dije: "Maestra, ¿por qué mi hijo se sacó una $A$ en su examen o su trabajo, y usted está poniendo una B? Maestra: "Oh, su hijo no le informó que él entregó su trabajo tarde." Elizabeth: "Él no me lo dijo." Y es allí donde es importante acercarse, y la comunicación con los maestros. Y cuando me vio mi hijo, él abrió unos "ojototes" porque él sabía porque tenía una B, y él no pensó que yo fuera ir hablar con la maestra. Él pensó que solo iba decir "Yo no sé," y no se imaginó que yo fuera ir hablar a la escuela, pero si fuí. Y mi hijo se dió cuenta que no puede ocultar cosas, que tiene que decir las cosas como son. Asi nosotros vamos entender más lo que los maestros hacen [sic].

[Well, many times when one of my children has a bad grade. For example, one time, my son came home with a B, and he told me, "No! I got an A on this"-that's all he said. I got upset and went to school to talk to the teacher-it was geography. I said to the teacher, "Why did you give my son a B when he got an A on his exam or assignment?" She said, "Oh, did your son tell you that he handed in his work late?" I said, "No, he did not tell me that." And these are the occasions where it is important to approach the teachers and communicate with them. When my son saw me at school, his eyes were wide open because he knew the reason he had a B, and he did not think I was going to talk to the teacher. My son then realized that he could not 
hide things from me, and that he had to tell me the things just as they were. That way, we as parents, will better understand what teachers do.]

Interviewer: Siempre es preferible decir la verdad, porque si no después... [risas].

[It is always better to tell the truth, because if you don't, later on... [laughs].

Elizabeth: Sí. Si no después de todos modos va salir. Bueno, yo soy una mamá que de todas maneras voy y habló, pero mi hijo no sabía. Creo que tenía pocos años aquí, y no pensó que fuera ir a la escuela, ipero si fui!

[Yes. The truth will eventually come out. Well, I am the type of mother who will go to school and talk to the teacher, but my son did not know that. I believe we had been here for only a few years, and he did not think I would have gone to school, but I did!]

In this part of Elizabeth's interview, we see an immigrant parent, who has only been in the United States a few years, being proactive about her child's homework and communicating clearly with her teacher. Through this approach at trying to increase communication and collaboration with her child's teacher, Elizabeth educated herself about the grading system at her son's school, how to communicate effectively and frequently with her child's teacher, and how to use the school's assessment system as a way to improve her own child's success in school. By working at and insisting upon a stronger parent-teacher collaboration with her child's teacher, Elizabeth helped her own child understand the importance of doing their best in school, but also helped the teacher understand how much she and other immigrant parents wanted to be involved in the educational process for their children.

\section{Theme 4: Empowerment through listening to and amplifying parents' voices}

A final theme that cut across the responses of immigrant parents in the study was the need for teachers and other educators in school settings to both listen to and amplify the voices of parents and their children. As they looked back on their sharing of their own experiences and the experiences of other parents in the project, parents began to realize the power of their own voices as individual parents and also as a collective group of parents with similar aspirations, personal resources, and obstacles they've faced within schools and within society. They also began to name how important it was for schools to provide a means and a method by which to both amplify and listen to their voices and ideas, as they relate to the education of their children and their roles in the schools of their children. Immigrant parents and their children have empowering and engaging ideas about schools and their educational and vocational aspirations for their children for their future. In what ways are schools responding to these voices and providing opportunities for the voices of children and parents to be heard and honored?

Carolina, for example, believes that parents need to speak up for their children and also be more present in school. She shares during a weekly work group meeting that, through her involvement in the Photovoice project, she learned that parents need no longer be afraid to be embarrassed by their beginning level of English, but empowered that they have opportunities to learn English at school and learn from each other.

Carolina: Tal vez tu hijo te va platicar, pero en ocasiones estas ocupada y no tomas el tiempo para escucharle. Entonces pienso, que en la manera que nuestros hijos pueden tener éxito es principalmente escuchándoles, preguntándoles, yendo a las escuelas, ir a las reuniones, convivir con otros padres. Y que creo que no deben de tener miedo o tener vergüenza, porque no es ignorancia, es simple y sencillamente que no es tu idioma, pero si a ti te gusta, también puedes aprender. Hoy en día hay muchos programas donde puedes ir aprender inglés como segunda lengua u otras lenguas. A mí me gusta y me encanta hablar con la gente; nunca he ido a la escuela a aprender inglés, pero hablando con la gente me han enseñado un poquito [sic]. 
[Sometimes we are busy and don't take the time to listen when our child wants to talk to us. I think that a way our children can be successful, is mainly by listening to them, asking them questions, going to school, going to meetings, and interacting with other parents. I think parents should not be afraid or feel embarrassed; it is not being uneducated, it is simply that English is not our language, but if you like it, you can learn it. Nowadays, there are many programs that teach English as a second language, or even other languages. I like and love to talk to people, and even though I have never gone to school to learn English, I have learned some, by talking to people.]

Carolina underscores the ways in which parents can learn and become empowered through learning English at school, but also through the outright refusal and rebuttal of society's label of them as "ignorant." Learning English is a difficult task, but achievable through the help of others within her parent group and resources available at school. However, she realizes that schools also need to reach out and provide these opportunities through creating spaces and opportunities for immigrant parents to meet each other, to learn English, and to share with educators at school their hopes for their children in school, their concerns, and their questions.

Carolina: Creo que haciendo más proyectos como este, de Photovoice, o hacer diferentes proyectos con los latinos. No importa de dónde vengas, quién seas, de dónde llegaste o a dónde vayas, lo importante es dejar saber a la gente que no están solos. Que no están solos y que tienen voz, que tienen talento, y que alcanzando el éxito, ellos como padres, sus hijos van a tener más éxito todavía. Creo que si los padres tienen éxito y los hijos tienen éxito, los maestros tienen mucho más éxito.

[I think that by doing more projects like Photovoice, or different kinds of projects with Latino people. It does not matter where you come from, who you are, where you arrive from, or where you are going. What is important is to let people know that they are not alone, that they have a voice, have talent, and if they, as parents, can achieve success, and their children are successful, the teachers can be more successful.]

Through opportunities, like the Photovoice project, Carolina sees that she and her fellow parents are not alone and that they can have a voice, that they have talent, and can achieve success. As she shares in this excerpt, "It does not matter where you come from, who you are, where you came from and where you are going. What is important is to let people know that they are not alone."

While Carolina uses the imagery of parents finding their voice through the project, Ariela talks about how the project gave her the opportunity "to speak and how to say how I feel and how I can act in a way so that people understand...." Photovoice provided her with multiple opportunities to name what she was feeling, to express herself via photos, and to empower her through her increased attempts at communicating with her peers and teachers. Ariela states:

Ariela: Número uno es conocer el proyecto, porque nunca lo había hecho. Otra, es muy bonito de tomarle importancia a las fotografías, que las fotografías hablan, también aprendí a cómo hablar, a cómo decir lo que uno siente, y cómo ponerlo de una forma que la gente pueda entender. Es un proyecto nuevo para mí, parece que apenas estoy en la escuela, no sé, pero me gusta porque habla de mi familia, de mi esposo, de mis hijos, de mis vivencias, de mis padres, hermanos. Me gusta porque incluye de todo [sic].

[First of all is to get to know the project, because I had never done one. Also, it is beautiful to value the pictures, because the pictures have something to say. I also learned how to speak, how to say the way I feel, and how to express it in a way that people could understand it. It is a new project for me; it seems that I am just now in school. I don't know, but I like it 
because it shows my family, my husband, my kids, my experiences, my parents, and sisters. I like it because it covers all aspects.]

Since she had not had been afforded opportunities to attend formal schooling past her elementary school years, Ariela mentions that she feels like she is "just now in school" and learning about herself. What makes her most proud of all her work in the project is that her final poster is inclusive of everyone that she loves within her family and allows her to the opportunity to share more photos and stories about "my family, my husband, my kids, my experiences, my parents, and sisters. I like it because it covers all aspects."

Finally, Carolina states in her interview that she is thankful that the project taught her many things about the power of her own voice and the rights that she has as a parent in the MVSD.

Carolina: Creo que lo principal es dar voz, dar vida, exigir tus derechos de manera respetuosa, de manera amable. Y que no te sientas humillado, no te sientas menos, porque todos somos iguales, profesionales o no profesionales, todos somos iguales. Y lo que me orgullece y me siento tan feliz de que me hubieran invitado a participar en este proyecto, y que haya recursos y personas que estén disponibles para este tipo de proyecto, porque a final de cuenta, todos estamos ocupados, todos tenemos una vida ocupada.

[I think the main thing is to give voice, give life, demand your rights in a respectful and friendly manner. That you should not feel humiliated, nor feel less than others; we are all equal, professionals or not, we are all the same. What makes me feel proud and happy, is that I was invited to participate in this project, and there are resources and people available for this type of project, because at the end of the day, everyone is busy, we all live a busy life.]

Carolina recognizes that, through participation in the Photovoice project, parents have the right to give voice and life to their own unique stories; that respectfully demanding one's rights is important. She also encourages her fellow immigrant parents to not feel less than other parents by acknowledging their own funds of knowledge, accessing them, sharing them, so they can feel "we are all the same" instead of being marginalized or treated as "the other." Additionally, she reflects on the pride and happiness that was developed in her by the opportunity to participate in the Photovoice project.

\section{Discussion}

During the course of this project, the research team unearthed critical counter-narratives of Spanishspeaking immigrant parents that described their unique experiences of arriving in the United States, and how these experiences inspired and motivated them to support their children to do well in school. In contrast to popular thought, parents repeatedly shared their wish to become more engaged and involved in their children's schools, and to partner directly with their children's educators. Overall, the critical counter-narratives provided by immigrant parents in the study show strong evidence and support for the importance of teachers listening to and amplifying immigrant parent voices to better respond to their hopes of becoming more involved in their children's classrooms and at their children's schools more generally.

Throughout the project, parents described their own experiences in coming to the United States, and how their personal experiences of a lack of access to school and discrimination within society served to activate their dreams for their children to become educated and to gain access to higher education and a productive career. Education was described by parents repeatedly as la herencia, or "the inheritance," which parents are trying to offer to their children based upon their own experiences with education, both formal and informal. Ariela, for example, recounted that, "We had never attended school either. The little bit we knew, we learned it from our mother. Our 
blackboard was the wall of the house...." This deeply personal account magnifies for us, as readers, the depth of passion and commitment for educational opportunities Ariela built over time and the ways in which she cares deeply for her children's access to public education. Additionally, other parents described their experiences as English language earners themselves, the stories of their own perseverance in schools, and the inheritance of education that they work at every day to offer to their children. The tremendous caring, inspiration, and motivation that immigrant parents wish to share with their children should be viewed as a valuable asset for teachers, administrators, counselors, and other support staff in schools looking for ways to establish more collaborative and inclusive home, school, and community partnerships.

Parents also often spoke of the "gifts and strengths" that they hold as individuals through the stories they shared about overcoming barriers upon arrival in the United States, finding jobs, and generally persevering through obstacles they've faced in their lives. For example, Carolina stated in her interview that when she first arrived in the United States, she learned English by herself at home when she could "...turn on the TV and the radio, and pick up any book that looked interesting and really try to understand what I said. That was my big schooling, and that is the reason why I speak some English." Some parents shared their gifts as tangible resources to teachers of their children and to the school more generally through volunteering their time to work one-on-one with students with their schoolwork, or creating items that could be auctioned at school fundraisers. Other parents shared stories of perseverance that demonstrate less tangible, but highly meaningful, funds of knowledge that can be used to support their children's own perseverance in schools that do not always accept them (Moll et al., 2013; Vélez-Ibañez \& Greenberg, 1992). For example, Ariela's story of how she did not have much formal schooling, but tried her best to learn through a family literacy program in her village, is an example of a compelling story of perseverance and resourcefulness that educators can draw out from their students and parents and then can use these types of stories to motivate students to want to succeed in schools themselves. When teachers in schools do not consciously look for and unearth these counter-narratives in the parents of their students, the gifts, talents, and strengths of parents are often overlooked as a means to productively and positively build on previous student learning, and the desire of immigrant parents to be meaningfully involved in the education of their children in public schools is left unacknowledged and not galvanized in the service of the school community.

Parents in this project also clearly stated their desire to be partners in their children's education. Not only did parents describe the benefits of having their students see them in the school as volunteers, but some described successful conversations with teachers that led them to build their own understanding of their children's experiences. Elizabeth, for example, encouraged other immigrant parents in the project to get involved at their children's school by stating, "There are many opportunities at the school to volunteer, and this is important because children notice everything, and feel proud of us, not only because we work and prepare food, but we can also do activities for the school... I think they feel proud when they see us at school." Often schools have students act as oral interpreters across home and school language, but as Elizabeth described in this article, her direct communication with teachers provided her with a different and important connection to her child's teacher about grades, her child's effort in school, and how she could support and motivate her child at home. Not only did she find out that what her child had communicated with her about his grades was incorrect and misleading, but Elizabeth also demonstrated her own resiliency, strength, and sense of agency in going into the school to speak directly with the teacher as an advocate for her own child and to signal her desire to be a willing and complementary partner to the work of her child's teachers.

Finally, the parents in the project shared that they were empowered through the Photovoice process implemented in the project and, as they were individually empowered to consider their own stories and their beliefs and expectations for their children in schools, they collectively empowered each other. They encouraged each other to become involved in the schools of their respective children and to "interact with other parents" to form collaborative groups of engaged parents. 
While schools often operate with what they claim is an "open-door policy" for communication with parents, the parents in this study creatively sought to create additional, meaningful opportunities where they could have a greater impact upon the classrooms and schools of their children. Together, they created and shared powerful examples of ways in which they tried to impact their child's experience in schools through their willingness to volunteer their time, energy, and support for teachers at their children's school. The ongoing discussions about their own parental involvement in their children's schools created an organic and positive meeting space among the parents where they visibly demonstrated support, encouragement, and care towards one another to all be involved in the respective schools of their children. Carolina summed up the experiences of her peer parent group well when she stated that, "What is important is to let people know that they are not alone." The Photovoice project described in this article became a tool for empowerment and parental engagement in schools that had not otherwise existed formally or informally for this parent population.

\section{Implications}

The parents' critical counter-narratives described in this study invite further reflection by teachers, administrators, and other support staff who work in public school settings. Through this study, educators are reminded to repeatedly call into question and interrogate the majoritarian story/master narratives that abound in popular discourse about the interest and role of immigrant parents of color in the education of their children. These master narratives all too often are built on deficit paradigms in which immigrant parents are too busy with work to care about the education of their children, are uninterested in supporting teachers in schools, or do not see the value of their participation in schools.

The counter-narratives we unearthed through our work with immigrant parents provide multiple ways of deconstructing these problematic master narratives. We invite teachers to be conscious of the multiple truths and ways of being that can be shared by parents of culturally and linguistically diverse backgrounds (Author, in press). It is critical for educators to gain understanding and perspective about the ways in which master narratives are alive and well in schools and how these master narratives often keep educators from understanding the culturally and linguistically diverse perspectives of immigrant parents. If we do not know that these master narratives exist, it becomes much harder, if not impossible, to interrogate, let alone dismantle them.

In education, the master narrative relies on the perspective of education from a dominant culture adult lens that is typically White, female, and middle-upper-class (Bireda \& Chait, 2011). Through this culturally mismatched lens, schools have a tendency to operate through use of a strong colorblind theory or deficit theory which either ignores the diversity of experiences of immigrant families or, worse, blames them for their perceived deficits and cultural ways of knowing, doing, and participating. The critical counter-narratives shared by parents in this study provide us with evidence that refutes these deficit orientations and points to the perspectives of parents strongly committed to the promise of public education for their children and their willingness to support their children in their quest for higher learning.

The research in this study also highlights the need for teachers, administrators, and other school stakeholders to re-think parental outreach and home-school communication, to move away from deficit-based thinking about immigrant parents, and instead to focus on and highlight a strengthsbased approach to unearthing the hopes and aspirations of immigrant parents for their children in public school in the United States. Unearthing the critical counter-narratives of Spanish-speaking immigrant families can offer a bridge to enhanced communication between teachers, parents, and students; an important opportunity to dismantle current myths that impede our willingness and ability to engage immigrant families in their child's education; and additional creative ideas to engage in more culturally responsive educational practices in our work as educators.

For example, through this study, we learn firsthand examples of how Spanish-speaking immigrant families operate from a collective lens versus an individual lens (Trumbull, Rothstein-Fisch, 
Greenfield, \& Quiroz, 2001) as they account for the educational experiences of children and adults in each family and the interconnectedness they seek between their home and the schools of their children. We also learn that, instead of assuming that a lack of formal education limits a child's future, educators can build on the described desire and passion for education that many of the parents described in their projects and interviews. We ask educators to consider further how teachers in schools might offer multiple and creative opportunities for families to share their stories with their children without using a colonist perspective, but a co-creation model that is intentionally inclusive and uses a collectivist lens such as the Photovoice project described in this article. We need to become inspired, committed, and motivated to create new ways of inviting families into our classrooms, and to identify explicit ways we can look to build on the family's culture in assignments and projects we assign to our students.

Culturally responsive teaching includes incorporating multiple aspects of students' cultural experiences as part of their learning (Trumbull \& Pacheco, 2005). Examples of assignments can include family interviews, student or family crests (made using textiles, technology, or paper and crayons), and student/family collages that can be interdisciplinary assignments inclusive of the arts, writing, math, science, and social studies. One parent in the study described how a teacher assumed that all of the Mexican parents in the classroom knew how to make piñatas when she asked for parent volunteers to make them for an upcoming event. It behooves us all to not fall into these stereotypical traps. Instead, we can begin to create a new assumption-that all Spanish-speaking immigrant parents have rich historical and cultural perspectives to share, and that their individual and collective stories can and should support their child's learning. Although we often hear that immigrant parents do not care or value their children's education, we heard from the parents in this study and their critical counter-narratives that Spanish-speaking immigrant parents do indeed care about their children's education and care deeply about the inheritance of education they wish to leave behind for their children (herencia para los ninos) and about the importance of education in helping their child become a good and respectable person in the eyes of society (person de bien).

Finally, the counter-narratives offered in this article remind us of the importance of building on Moll's (1992) research on funds of knowledge by continuing to use an assets-based approach in our own teaching and relational practices as educators and how parents' funds of knowledge are critical to unlearning and re-learning what parents, caregivers, and families know, share, and can contribute as part of their child's experience in schools. Moll (2010) describes the importance of these funds of knowledge when he writes, "For so-called minority children, especially in the contemporary social context, educational resources and opportunities must include integrating their language and cultural experiences into the social and intellectual fabric of schools, much as these have always been seamlessly integrated into the education of privileged White children" (p. 454). Studies have also examined the productive and generative ways to use funds of knowledge. For example, a study highlights 14 Puerto Rican households with regards to funds of knowledge and finds the value of literacy in ways that have otherwise gone unnoticed (Mercado, 2005). In another case study, it was revealed that 20 adults from the community participated in a funds of knowledge project and this work positively contributed to the learning process of children. The funds of knowledge were incorporated into classroom instruction and were connected to homework assignments, and both strategies increased literacy in English and Spanish (Moll, 1992).

The counter-narratives of the projects and interviews of immigrant parents in this study demonstrate how Photovoice can be used as a vehicle for uncovering funds of knowledge and parental strengths and commitments as a way to develop and strengthen home-school connections. Photovoice can be one way to help empower immigrant parents and other parents whose voices have been systemically silenced or diminished in schools and classrooms. The themes uncovered by this study support much of the research on the funds of knowledge of immigrant parents and shine a light on how the parent participants supported their children and schools in both visible and invisible ways. 
Though often "hidden" members of school communities, immigrant parents do have important contributions to make to the success of a school and individual classrooms within the school. Unearthing and highlighting their critical counter-narratives is only the first part of the important work ahead of us as educators in today's public schools. We also need to be consciously and conscientiously working to use the information shared by parents productively and creatively as important resources within the classroom and within our schools. Finally, we, as educators, need to be committed to engaging more collaboratively and purposefully with our immigrant parents and their children in schools around the country. By committing ourselves to this work, we will act in ways that genuinely welcome and encourage immigrant parents and their children as valued educational partners who have invaluable insights, innovative ways of looking at old problems that exist in schools, and collective wisdom to share with us all in our shared classrooms, school communities, and public spaces.

\section{References}

Auerbach, S. (2007). From moral supporters to struggling advocates: Reconceptualizing parent roles in education through the experience of working-class families of color. Urban Education, 42(3), 250-283. doi:10.1177/ 0042085907300433

Bireda, S., \& Chait, R. (2011). Increasing teacher diversity: Strategies to improve the teacher workforce. Retrieved from https://www.americanprogress.org/issues/education/report/2011/11/09/10636/increasing-teacher-diversity/

Castro-Salazar, R., \& Bagley, C. (2010). "Ni de aquí ni from there": Navigating between contexts: Counter-narratives of undocumented Mexican students in the United States. Race Ethnicity and Education, 13(1), 23-40. doi:10.1080/ 13613320903549651

Ceballo, R. (2004). From barrios to Yale: The role of parenting strategies in Latino families. Hispanic Journal of Behavioral Sciences, 26(2), 171-186. doi:10.1177/0739986304264572

Charmaz, K. (2006). Constructing grounded theory: A practical guide through qualitative analysis. Thousand Oaks, CA: Sage.

Corbin, J., \& Strauss, A. (2008). Basics of qualitative research (3rd ed.). Thousand Oaks, CA: Sage.

Delgado-Gaitan, C. (1994). "Consejos": The power of cultural narratives. Anthropology \& Education Quarterly, 25(3), 298-216. doi:10.1525/aeq.1994.25.3.04x0146p

Gaetano, Y. (2007). The role of culture in engaging Latino parents' involvement in school. Urban Education, 42(2), 145-162. doi:10.1177/0042085906296536

Gabriel, M. L. (2011). Voices of Hispanic and Latina/o secondary students in northern Colorado: Poetic counterstories. Fort Collins, CO: Colorado State University.

Gabriel, M. L. (2015). Building teacher skill by learning about racialized experiences described by Latin@ middle and high school youth. Cuaderno de Investigación en la Educación, 30, 38-54.

Gagne, C., Bowers, A., Russinova, Z., Bloch, P., \& McNamara, S. (2010). Combating prejudice and discrimination through Photovoice empowerment: Leader's guide. Boston, MA: Boston University Center for Psychiatric Rehabilitation.

Guerra, P. L., \& Nelson, S. W. (2013). Latino parent involvement: Seeing what has always been there. Journal of School Leadership, 23(3), 424-455.

Guerrero, A., \& Tinkler, T. (2010). Refugee and displaced youth negotiating imagined and lived identities in a photography-based educational project in the United States and Colombia. Anthropology \& Education Quarterly, 41(1), 55-74. doi:10.1111/aeq.2010.41.issue-1

Howard, G. (2006). We can't teach what we don't know: White teachers, multiracial schools. New York, NY: Teachers College Press.

Jasis, P., \& Ordoñez-Jasis, R. (2004). Convivencia to empowerment: Latino parent organizing at La Familia. High School Journal, 88(2), 33-43. doi:10.1353/hsj.2004.0023

Jasis, P., \& Ordoñez-Jasis, R. (2012). Latino parent involvement: Examining commitment and empowerment in schools. Urban Education, 47(1), 65-89. doi:10.1177/0042085911416013

Landsman, J., \& Lewis, C. (Eds.). (2006). White teachers/diverse classrooms: A guide to building inclusive schools, promoting high expectations, and eliminating racism. Sterling, VA: Stylus.

Leech, N. L., \& Onwuegbuzie, A. J. (2008). Qualitative data analysis: A compendium of techniques and a framework for selection for school psychology research and beyond. School Psychology Quarterly, 23(4), 587-604. doi:10.1037/ 1045-3830.23.4.587

LeFevre, A., \& Shaw, T. (2012). Latino parental involvement and school success: Longitudinal effects of formal and informal support. Education and Urban Society, 44(6), 707-723. doi:10.1177/0013124511406719 
Lopez, G., Scribner, J., \& Mahitivanichcha, K. (2001). Redefining parental involvement: Lessons from high-performing migrant-impacted schools. American Educational Research Journal, 51(1), 253-288. doi:10.3102/ 00028312038002253

McCarty, T., Romero, M., \& Zepeda, O. (2006). Reclaiming the gift: Indigenous youth counter-narratives on native language loss and revitalization. The American Indian Quarterly, 30(1), 28-48. doi:10.1353/aiq.2006.0005

Mercado, C. I. (2005). Seeing what's there: Language and literacy funds of knowledge in New York Puerto Rican homes. In A. C. Zentella (Ed.), Building on strength: Language and literacy in Latino families and communities (pp. 134-147). New York, NY: Teachers College Press.

Milner, H. R. (2008). Disrupting deficit notions of difference: Counter-narratives of teachers and community in urban education. Teaching and Teacher Education, 24(6), 1573-1598. doi:10.1016/j.tate.2008.02.011

Moll, L. C. (1992). Bilingual classroom studies and community analysis: Some recent trends. Educational Researcher, 21(2), 20-24. doi:10.3102/0013189X021002020

Moll, L. C. (2010). Mobilizing culture, language, and educational practices. Educational Researcher, 39(6), 451-460. doi:10.3102/0013189X10380654

Moll, L. C., Soto-Santiago, S., \& Schwartz, L. (2013). Funds of knowledge in changing communities. In K. Hall, T. Cremin, T. B. Comber, \& L. C. Moll (Eds.), The Wiley Blackwell international handbook of research on children's literacy, learning and culture (pp. 172-183). London, UK: Wiley Blackwell.

National Collaborative on Diversity in the Teaching Force. (2004). Assessment of diversity in America's teaching force: A call to action. Washington, DC: National Education Association.

Ramirez, A. (2003). Dismay and disappointment: Parental involvement of Latino immigrant parents. The Urban Review, 35(2), 93-110. doi:10.1023/A:1023705511946

Solórzano, D. G., \& Yosso, T. J. (2001). From racial stereotyping and deficit discourse toward a new critical race theory in teacher education. Multicultural Education, 9(1), 2-8.

Solórzano, D. G., \& Yosso, T. J. (2002). Critical race methodology: Counter-storytelling as an analytical framework for educational research. Qualitative Inquiry, 8(1), 23-44. doi:10.1177/107780040200800103

Solórzano, D. G., \& Yosso, T. J. (2009). Critical race methodology: Counter-storytelling as an analytic framework for educational research. In E. Taylor, D. Gillborn, \& G. Ladson-Billings (Eds.), Foundations of critical race theory in education (pp. 131-147). New York, NY: Routledge.

Stanley, C. A. (2007). When counter narratives meet master narratives in the journal editorial-review process. Educational Researcher, 36(1), 14-24. doi:10.3102/0013189X06298008

Strack, R. W., Magill, C., \& McDonagh, K. (2004). Engaging youth through Photovoice. Health Promotion Practice, 5(1), 49-58. doi:10.1177/1524839903258015

Trumbull, E., \& Pacheco, M. (2005). Leading with diversity: Cultural competencies for teacher preparation and professional development. Providence, RI: Brown University and Pacific Resources for Education and Learning. Retrieved from http://www.alliance.brown.edu/pubs/leading_diversity/lwd_entire.pdf

Trumbull, E., Rothstein-Fisch, C., Greenfield, P. M., \& Quiroz, B. (2001). Bridging cultures between home and school: A guide for teachers with a special focus on immigrant Latino families. Mahwah, NJ: Lawrence Erlbaum Associates.

Valencia, R. R., \& Black, M. S. (2002). “Mexican Americans don't value education!"-On the basis of the myth, mythmaking, and debunking. Journal of Latinos and Education, 1(2), 81-103. doi:10.1207/S1532771XJLE0102_2

Valenzuela, A. (1999). Subtractive schooling: U.S.-Mexican youth and the politics of caring. Albany, NY: State University of New York Press.

Vélez-Ibañez, C. G., \& Greenberg, J. (1992). Formation and transformation of funds of knowledge among U.S.-Mexican households. Anthropology \& Education Quarterly, 23(4), 313-335. doi:10.1525/ aeq.1992.23.4.05x1582v

Villenas, S., \& Deyhle, D. (1999). Critical race theory and ethnographies challenging the stereotypes: Latino families, schooling, resilience and resistance. Curriculum Inquiry, 29(4), 413-445. doi:10.1111/0362-6784.00140

Wang, C. (1999). Photovoice: A participatory action research strategy applied to women's health. Journal of Women's Health, 8(2), 185-192. doi:10.1089/jwh.1999.8.185

Wang, C., Cash, J., \& Powers, L. (2000). Who knows the streets as well as the homeless? Promoting personal and community action through Photovoice. Health Promotion Practice, 1(1), 81-89. doi:10.1177/152483990000100113

Yosso, T. J. (2005). Whose culture has capital? A CRT discussion of community cultural wealth. Race Ethnicity and Education, 8(1), 69-91. doi:10.1080/1361332052000341006

Yosso, T. J. (2006). Critical race counterstories along the Chicana/Chicano educational pipeline. New York, NY: Routledge. 